\title{
From Record Economy to Entertainment Economy: The Trend of Popular Music Industry in the Chinese Mainland in the Last Thirty Years
}

\author{
Jiaran Ding and Lin Yu \\ College of Music ,Jiangxi University of Technology
}

Keyword: Popular music industry; Industrial environment; Industrial chain; Record economy; Entertainment economy.

\begin{abstract}
The development of popular music industry in Chinese mainland has gone through from the record economy to the entertainment economy. The record economy is dominated by the record industry, the record's sale revenue sustains the development of the entire industry. From the perspective of the industrial chain, the upper reaches of Chinese mainland's popular music industry refers to the organization and management of the record company, including the singer selection and management system, the production and advertisement of the album; middle reaches refer to the release of the record; the lower reaches of the record is the sale and copyright licensing. Chinese mainland's pop music has gone through more than 30 years, but as to forming process and the orientation of development of the pop music industry, academic circles has not yet done systematic research and academic retrospection, nor the formation of overall cognition for the industry.
\end{abstract}

\section{Introduction}

Follow the process of reform and open to the outside world, the Chinese mainland 's popular music industry has gone through thirty years' development, and the industry market has been preliminary developed, and also pop music industry chain has been established basically.During the development of the thirty years, the trend of the popular music industry in Chinese mainland has changed fundamentally, which is the theme of this research: from the record economy to the entertainment economy.

The record economy refers to the pop music industry which takes record industry as the center of the entire industry mechanism, where the record revenue supports the sustainable development of the entire industry. The recording industry is the industry mechanism which operates around the production, propaganda, distribution and sale of the record..

Entertainment economy refers to changing the pop music industry from the record industry into entertainment industry with a complete industrial chain including comprehensive record industry, concert, entertainer brokers and so on .That is, entertainment economy is taking a singer as a platform for a multi-angle commercial development, record as the main means of propagandizing singer and building reputation, prestige, and not the main channel to profit, whose income is mainly come from artists brokerage, endorsements ,concert and so on. The pop music industry has become a series of activities which take singer as the center.

No matter is the traditional music industry, or the digital music industry, should take music and singer as the core, which are the inseparable two parties in the pop music industry and also the core and basis of the industry's management. The singer is the final diagnosis of song, and also exists as a 
kind of independent music product, who can form the "idol worship" and become the basis for attracting consumers to consume steadily. "In the pop music culture, idol culture not only can not be excluded, but is one of the very important links. Without the idol culture, the pop music culture cannot be established". The entertainment economy integrates singers with music, embodying the complete pop music industry.

And it also shows that the mainland's popular music industry is entering the advanced stage of development from the elementary stage of the industry.

This paper will use the method of literature analysis to carry on academically combs. According to the time of order, Chinese mainland's pop music industry can be divided into traditional music industry which formed after the 1980s and the new century digital music industry. Draw on the perspectives of sociology, communication, economics and the research results of academia to reveal the process of the formation and transformation of the mainland popular music industry.

Although popular music is a necessary part of people's life, its theoretical research is still very deficient, and the theoretical shortage is not conducive to the development of industry practice. All sorts of practical problems of pop music need attention and research of theory, so does its history. Chinese pop music needs to improve its theoretical system.

Since the emergency of pop music in Shanghai in the 1920s and 1930s, some scholars began to pay attention to this new thing. By far there are a lot of articles and books about Chinese pop music. And a number of articles and books involved some content about industry, such as copyright, brokerage contracts and other specific aspects, or to explain audio-visual industry and recording industry, which provide us with indispensable resources to understand a general view of the development of popular music in the mainland and its existing problems.

Industry is the fundamental way to realize the value of music. Academic review and discussion on the process of formation and transformation of pop music industry in mainland, is not only beneficial to the perfection of theoretical research, but also can further clarify the root of the problems existing in the development of the industry, providing the reference and guidance for the establishment and perfection of digital music industry model.

Industrial accumulation- Formation of Industry chain-Reformation of Industry chain. In 1978, China's society, economy and the culture entered a new stage of development. With the help of CCTV, a national media, pop music gradually moves from the underground to the mainstream of society. The growth of the needs for social cultural entertainment, the gradual popularization of television media, the limited support of the government and other factors, make pop music this emerging thing grow rapidly in various controversy. With the gradual reformation of economic system, and the gradual establishment of principle of commercialization, people have begun to realize the commercial attribute of cultural products including pop music. The establishment of the Pacific audio-visual company, which first takes entertainment and profit maximization as the priority, is the symbol of the modern musical industry. With the introduction and impact of the advanced creative concept of pop music of Hong Kong and Taiwan, Guangdong, the birthplace of pop music industry in Chinese mainland, began its initial industry from the original "looking for tapes". The popularization of video tape recorder and video tape makes the recording industry audio and video simultaneously, so it is called the audiovisual industry. The lack of policies, laws, etc. ,and unsoundness of market mechanism, not only caused the first decline in the end of the 80's pop music, but also left potential problems for the music industry. 
Reform and opening in 1978 brought a "social transformation", opening a new era for the economic, cultural and social life in China. The commercialization of culture is always an important part of the historical process of the social transformation in the contemporary China. The gradual implement of the reform of economic system, the gradual establishment of commercialization principle, and the commercial attribute of the cultural products including the pop music are gradually recognized and accepted by people.

"What Reform and opening bring us is a quiet consumer revolution", which expands the diversity and personality of consumer choice, and brings the growing demand on social and cultural entertainment. In late 1979, Li Guyi, answering the requirement of the audience, sang the township love, during a concert in million Museum, arousing audience's prolonged applause. There was a "New Star concert" in the capital stadium in September 1980, 23 to 24th.Beijing Evening News, the host of the concert, reported that, there had been people who rushed to the ticket office and waited for the ticket at 12:00o'clock midnight. From the beginning at 9:00am on the 19th, less than three hours, more than 30,000 tickets had been sold out. ....."

Government's policy support is an external factor that can not be ignored in the industry health and the rapid development. At this stage, people have realized that the healthy development of the pop music can not do without the government's management and policy support .As the professionalism and commercialization of popular music, the strengthened management is necessary. We can refer to the management method overseas, combine with the situation of our country and current status and make a set of feasible management method. Managing it is to love it, to help it embarked on a path of healthy development.

In 1982, December 23, the Department of radio and television formulated Interim Provisions of management of the audio and video products, clearing management department of the audio and video product, audio-visual publishing units and the approval procedures of the establishment of rerecording unit and the legitimate rights and interests of the performers and authors. Since then, a lot of audio and video publishing organizations and units have been established.

Around the 1980s, "Cavitation" as the predecessor of the broker emerged. Its appearance met the entertainment needs of people to a certain extent, but it focused too much on economic interests and there were many shoddy with inferior style, seriously disrupting the current performing market to a large extent. Because of this, the state promulgated Reports on the unauthorized organization of the actors for the business performance in 1983 to regulate the market. For the chaotic situation of the cultural performance market, the Shanghai company had established the culture broker firm to manage the social culture brokers. The Notice of the State Council approved the Ministry of culture on accelerating and deepening of performing arts groups system reform views in 1988 "proposed to "build performance broker system, organize and develop performance company of the state, the collective and the individual", and the concept of "acting broker" appeared in official documents for the first time.

The cultural market began with the music cafe held in Guangzhou Orient Hotel in 1978. The first music café of the new period held in Guangzhou Orient Hotel, was reviewed as an important symbol of the re-emergence of entertainment and cultural market in China. The music café held in Oriental Garden Hotel restaurant had been approved by the Propaganda Department of Guangzhou and the Bureau of culture of Guangzhou, and the competent department of music café - social culture management office in Guangzhou promotes its healthy development through formulating strict rules and regulations and makes demand on the repertoire stipulating that inland original works or folk and 
works of art must take up a certain proportion and requiring employers to organize the short-term training for the teahouse singer to promote positive creation and development of original music. May 31,1985 , In order to further strengthen the team performance management of music cafe, Municipal People's government announced the notice about Instructions on Strengthening the Management of Music Café Show to people's government of districts and counties, Government's subordinate units and the row units. It can be said that the Guangzhou municipal management department plays an important role in the development of Guangdong pop music, even the continental pop music.

In February 1987, the Ministry of culture, the Ministry of public security, the national industrial and commercial bureau issued jointly A Notice on Improving the Management of the Business Dance, clearing legitimacy of holding business dance, and making cultural business activities officially a legal component of socialist culture in China.

In 1988, the Ministry of culture, the State Administration for Industry and Commerce issued a Notice on Strengthening the Management of Cultural Market, which formally proposed the concept of "cultural market", at the same time cleared the management scope, tasks, principles and guidelines of cultural market, ending chaotic situation of cultural market. This indicates that the status of Chinese "cultural market" had been recognized officially. In 1989, the State Council agreed to establish the Cultural Market Management Bureau in the Ministry of culture, since then the management system of national cultural market began to build. Karaoke music, dance halls, cafes and other entertainment developed rapidly.

The forum of management work about national culture and entertainment market is held in 1990 to study the problems and solutions of karaoke, dance halls, "karaoke" halls, and discuss the measures for the administration of the "three halls", urging the management of "three halls" to step in the legal and scientific track. The forum developed a Management Approach to Business Entertainment Sites, and other administrative regulations.

People have recognized the necessity and urgency of copyright protection. At the end of 1988, a group of vulgar tapes were released by Audiovisual Publishing departments, causing harmful effects on society. Some audio-visual publishing units' awareness of copyright was weak, and they did not respect the legitimate rights and interests of authors and even engaged in piracy.

In 1980, China entered the world intellectual property organization, accelerating the pace of intellectual property protection. The fifteenth session of the Standing Committee of the Seventh National People's Congress passed the copyright law of the People's Republic of China in in1990,September 7.It is formally implemented in 1991, june 1.

The copyright law is divided into 5 chapters and 56 items, the main content is about the subject and object of the copyright, the attribution of the copyright, the protection period and its restriction and the copyright license contract, it also provides for the publication, the performance, the sound recording and video recording, the broadcasting station, the television station and so on. But the 4th chapter of the forty-third section of the provisions of the fourth is not conducive to copyright protection. It stipulates that the broadcast station, the television station , Business broadcast can broadcast published sound the recording without the agreement of copyright owner, the performer, the recording producer and they also need not pay for them. The basis of this law is clearly based on "mouthpiece" the character of radio and TV in history. Since the large-scale reform of broadcasting system in the late 1980s, more and more radio and television programs has a strong commercial Except a large number of programs with advertising ,quite a number of shows have been invested directly by the society, which is completely a commercial activity. Therefore, the recording industry 
lost one of the greatest sources of royalty. Not only that, just because broadcasting system do not pay royalties, many other commercial systems, especially dance hall and karaoke system, cultural industry with great business benefits, also use this as an excuse to refuse to pay royalties.

Pop music is a industry based on copyright, and copyright law is a special law guaranteeing the economic interests of the music industry and protecting legitimate rights and interests and the sources of industry profits of right-owners through protecting the output products - songs, tape, disc, etc. from illegally copying. But provisions in The Copyright Law in 1990 did not play a role in music copyright protection, instead caused music industry to lose the most important source of income of copyright authorization in the music industry and later also brought great hidden trouble for the healthy development of the industry.

During this period, the government' supervision was limited, "prison song wind" formed by the "prison song" taking prisoner as the theme of the "readme" and Folk Music represented by Jianyunfei's Grape Skin were good proof, among which, "prison song” was released by Studios when Video movie actor Chi Zhiqiang was released from prison. The continental pop music is actually at a marginal zone of the administrative supervision and the market adjustment, which hide trouble for the future development..

Around the 1980s, pop music in Taiwan and Hong Kong formally stepped into industrialization era driven by Warner, Polygram and other multinational record company and Japanese music industry mechanism. The presence of multinational corporations introduced the concept of artistandrepertoire $A \& R$, royalty system and other mature financial and business management modes as well as concert, ranking and other promotional methods, promoting Hong Kong and Taiwan to become the center of the entire Chinese pop music. The introduction of Hong Kong and Taiwan pop music, not only led to the upsurge of the first mass culture in the continent, also introduced advanced creative technology and creative concept. In this way mainland pop music began the accumulation and germination of industrialization.

At the beginning of the reform and opening up, only one state-run Record Corporation monopolized the record production and publishing which took service ideology as priority principle and gradually could not meet the growing cultural and recreational needs. At the beginning of the 1980s, Guangzhou Pacific AV companies and China Record Corporation Guangzhou Branch Company and Beijing Baihua audio equipment factory began to produce cassette, ending an era where the publication of recording was monopolized exclusively by China Record Corporation. Especially in 1979 Guangzhou Pacific audio company was established, which was the first recording company in mainland taking entertainment and profit maximization as the priority principle, and it drove the formal start of the music industry in the modern continent through cooperation with the Hong Kong Baili and the introduction of stereo equipment in the way of "compensation trade".

In the 1990s, the most important change was the rise of the mass culture, like a prairie fire, which became the mainstream of society and explored the era of mass culture. Economic globalization arising in the middle of 1980s,was recognized in the 1990s. Globalization not only includes the economic globalization, but also contains the cultural globalization, and it let the mainland pop music development involved in the trend of the world. The entrance into Chinese market of SONY and other international record companies as well as the entry of Japanese and Korean pop music at the he end of the 90's had a profound impact on the formation of the mainland's popular music industry mechanism. The wind of Hong Kong and Taiwan continues to blow and continues to show its enormous influence. The 1980's glory was brought by the cover of the song of Hong Kong and 
Taiwan under the drive of commercial motives. During this period, the introduction of Hong Kong and Taiwan tapes were limited. The change of objective environment made the audio-visual enterprises of mainland start to re-plan their own direction of development, leading to the establishment of pop music industry mechanism of mainland. In 1992, Deng Xiaoping's southern tour speech promoted China's reform and opening to the outside world, further accelerated the transition of the direction of the market economy, brought new development opportunity to the pop music culture. The wave of market gradually formed a marketing department including songwritersinger - record company, or traditional pop music industry chain including professional marketing company -record seller-user terminal equipment manufacturers-user. But the immaturity of market mechanism, the imperfection of industry chain, and the lack of management and legal made pop music of mainland experienced a brief climax from 1993 to 1994, stepping into the winter before entering the fruitful autumn. The downturn and recession of market had continued until the arrival of the new century.

Since 2000, the development of cultural industry including pop music industry was incorporated into the national strategic planning; he proportion of cultural consumption in people's social consumption has increased gradually and becomes a new consumption hot spot; the legal system has improved continuously and other aspects also gotten comprehensive improvement, all of this created a good social environment for the development of pop music industry. In 2001, China entered the world economic and Trade Organization. The permission of foreign investment into the audiovisual industry in China, not only brought the opportunity but brought challenges. The "localization strategy" of Warner and other multinational recording companies and Korean entertainment companies has a profound impact on the mainland pop music industry. The popularization of new media such as Internet, mobile phone, etc., and the emergence of digital music, has had a tremendous revolutionary effect on the whole traditional pop music industry. The network singer and the talent show become a new way to select singer for record company. The continuous hot of talent show makes the creasy of fans reach unprecedented degree. The biggest character of talent show is that the consumer base is the idol, not their music. The talent show singer drives the pop music industry in the mainland into an era of entertainment industry which takes idol as the business development platform and consumption point.

The reform and open policy in 1978 brought the revival and development of the industrialization of the mainland pop music. During the industrial accumulation period from 1978 to1990, Therecord company and singer cooperation is instant, because the cultural entertainment just started, the market competitionis not fierce,the record production of the

company is the creator's self-emotional expression. The tendency of market has not been formed; the form and function

of propaganda are single. Encouraged by the policy, the audio and video publishing organizations ha ve been established, and traditional

Music distribution channels are setup.

Teenagers consumer groups begin to form, but it doesn't show the uniqueness. Record sales revenue is the main sources of record companies to maintain operation and further development. Mainland has formed the traditional pop music industry chain from 1991 to 2000 . The industry system such as singer system, broker system, music producer system begin to form and establish. 
The rise of digital music have played a revolutionary role to the traditional pop music industry chain from 2001 to 2010.

Pop music is a spiritual product. It is the fact that we can't deny that pop music has become a kind of educational media which has the greatest influence on the youth community besides the family an $\mathrm{d}$ the school education. Recording companies should take the responsibility of the industry while considering the economic interests, $\mathrm{cr}$ eate a variety of positive music works and avoid vulgarity of pop music

In order to have healthy and sustainable development of Chinese pop music industry, we also nee $\mathrm{d}$ efforts in the following areas:

improve the policy environment

strengthen the legal system

develop supporting industry

\section{Reference}

[1] Written by Walter Benjamin, translate by Wang Caiyong: A brief History of photography+ The Work of Art in the Era of Mechanical Reproduction; 【Canada】 Written by Marshall Mcluhan, translate by He Daokuan: Understanding media- On the Extension of Human;

[2] Written by Paul Levinson, translate by He Daokuan: Phone: Unstoppable Call ;

[3] Written by Neal postman, translate by He Daokuan: Technological Monopoly: Cultural Surrender To Technology;

[4] Written by Neal postman, translate by Zhang Yan, Wu Yanyan: Amusing Ourselves to Death :The Passing of Childhood; Written by Li Wen: The Spread and Influence of Japanese Culture in China (1972-2002);

[5] Written by Albert Geleike, translate by Chen Xing, Fang Fang, revised by Cui Baoguo: Audio and Video Industry Management; Huang Huilin ,The Chief editor, Yin Hong, The Deputy Editor: The Research on Mass Culture in Contemporary China; Written by Yu Jianqiang: Media: Market-oriented trap; Written by Zong Xiaojun: The Secret of the Music Business. 